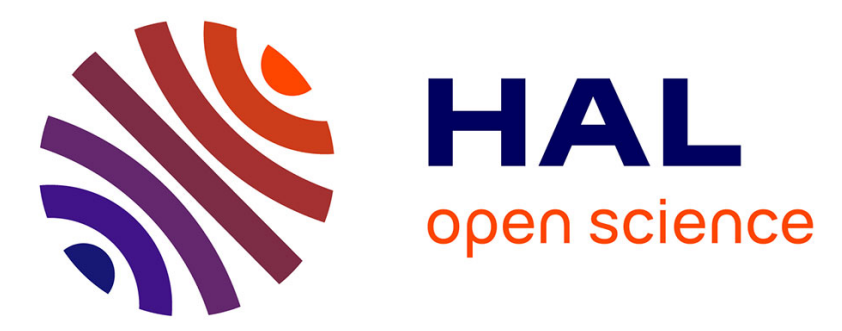

\title{
Forest recovery since 1860 in a Mediterranean region: drivers and implications for land use and land cover spatial distribution
}

Juliet Abadie, Jean-Luc Dupouey, Catherine Avon, Xavier Rochel, Thierry Tatoni, L. Bergès

\section{To cite this version:}

Juliet Abadie, Jean-Luc Dupouey, Catherine Avon, Xavier Rochel, Thierry Tatoni, et al.. Forest recovery since 1860 in a Mediterranean region: drivers and implications for land use and land cover spatial distribution. Landscape Ecology, 2017, 33 (2), pp.289-305. 10.1007/s10980-017-0601-0 . hal02096805

\section{HAL Id: hal-02096805 \\ https://hal.science/hal-02096805}

Submitted on 3 May 2019

HAL is a multi-disciplinary open access archive for the deposit and dissemination of scientific research documents, whether they are published or not. The documents may come from teaching and research institutions in France or abroad, or from public or private research centers.
L'archive ouverte pluridisciplinaire HAL, est destinée au dépôt et à la diffusion de documents scientifiques de niveau recherche, publiés ou non, émanant des établissements d'enseignement et de recherche français ou étrangers, des laboratoires publics ou privés. 


\title{
Forest recovery since 1860 in a Mediterranean region: drivers and implications for land use and land cover spatial distribution
}

\author{
Juliet Abadie $(\mathbb{D} \cdot$ Jean-Luc Dupouey - Catherine Avon - Xavier Rochel • \\ Thierry Tatoni · Laurent Bergès
}

\begin{abstract}
Context Land use and land cover (LULC) change is a major part of environmental change. Understanding its long-term causes is a major issue in landscape ecology.

Objectives Our aim was to characterise LULC transitions since 1860 and assess the respective and changing effects of biophysical and socioeconomic drivers on forest, arable land and pasture in 1860, 1958 and 2010, and of biophysical, socioeconomic and distance from pre-existing forest on forest recovery for the two time intervals.
\end{abstract}

J. Abadie ( $\square)$

Irstea, UR RECOVER, 3275, route de Cézanne, CS 40061, 13182 Aix-en-Provence Cedex 5, France

e-mail: juliet.abadie@irstea.fr

C. Avon

Semperfloris, Place de la République, 07000 Privas,

France

X. Rochel

University of Lorraine, EA 7304 LOTERR - CLSH, BP

13397, 54015 Nancy Cedex, France

\section{J.-L. Dupouey}

Forest Ecology and Ecophysiology Unit, French National Institute for Agronomical Research (INRA), University of Lorraine, Rue d'Amance, 54280 Champenoux, France
Methods We assessed LULC transitions by superimposing 1860, 1958 and 2010 LULCs using a regular grid of $1 \times 1 \mathrm{~km}$ points, in a French Mediterranean landscape $(195,413 \mathrm{ha})$. We tested the effects of drivers using logistic regressions, and quantified pure and joint effects by deviance partitioning.

Results Over the whole period, the three main LULCs were spatially structured according to land accessibility and soil productivity. LULC was driven more by socioeconomic than biophysical drivers in 1860, but the pattern was reversed in 2010. A widespread forest recovery mainly occurred on steeper slopes, far from houses and close to pre-existing forest, due to traditional practice abandonment. Forest recovery was better explained by biophysical than by socioeconomic drivers and was more dependent on

T. Tatoni

Mediterranean Institute of Marine and Terrestrial

Biodiversity and Ecology (IMBE), Aix-Marseille

University, CNRS, IRD, Univ. Avignon, Campus de St-

Jérôme, 13397 Marseille Cedex 20, France

\author{
L. Bergès \\ Université Grenoble Alpes, Irstea, UR EMGR, 2 rue de la \\ Papeterie BP 76, 38402 St-Martin-d'Hères, France
}


distance from pre-existing forest between 1958 and 2010.

Conclusions Our results showed a shift in drivers of LULC and forest recovery over the last 150 years. Contrary to temperate regions, the set-aside of agricultural practices on difficult land has strengthened the link between biophysical drivers and LULC distribution over the last 150 years.

Keywords Forest transition · Historical maps · Land cover change - Land use change - Logistic regression * Long-term · Northern Mediterranean · Transition matrix

\section{Introduction}

Human activities are estimated to have transformed or degraded some $50 \%$ of the land surface up to now, mostly through agriculture (Kareiva et al. 2007). One major issue of land use and land cover (LULC) change worldwide is biodiversity loss, through habitat loss and fragmentation and landscape homogenisation (Foley et al. 2005; Lambin and Geist 2006). The study of LULC change is of crucial importance for understanding how the past shapes current landscapes and ecosystem functioning, and to better anticipate the consequences of current landscape modifications (Antrop 2005; Kaim et al. 2016). LULC change is predominantly induced by human activities, which are conditioned by external constraints or facilitations (Lambin et al. 2001; Bürgi et al. 2004; Mitsuda and Ito 2011). Bürgi et al. (2004) defined five types of LULC change: natural, socioeconomic, political, technological and cultural but two groups are mostly considered: natural (or biophysical) and socioeconomic drivers (Wulf et al. 2010; Mitsuda and Ito 2011). Biophysical drivers (climate, topography, soil) contribute to the development of adapted vegetation and inhibit or ease land use, while socioeconomic drivers (population size and composition, land prices, infrastructure network, etc.) reflect direct or indirect human pressure on land (Mitsuda and Ito 2011). These two groups of drivers can be variably correlated or intrinsically intertwined (Mitsuda and Ito 2011), and so causal relationships between drivers and LULC change may be difficult to elucidate. Depending on the geographical context (lowlands or mountains), biophysical attributes can strongly guide human activities (density of settlement, transport infrastructures, proportion of agriculture) and thus be a major driver of land use compared with socioeconomic drivers (Odgaard et al. 2014).

After the last glaciation, forest cover became gradually predominant in European landscapes (Kaplan et al. 2016). Since the Neolithic, forest cover has lost ground to agriculture, with short periods of limited recovery (Kaplan et al. 2009; Barbier et al. 2010). A sudden upturn in forest cover, known as the forest transition (Mather 1992), occurred during the nineteenth century in Europe, due to land abandonment and land protection. In France, like in several other European countries, the drivers of forest transition were rural depopulation, improved crop yields, which reduced the need for agricultural expansion, the development of new sources of energy in addition to fuelwood and the development of transport infrastructures, which reduced the need for local subsistence (Mather et al. 1999; Koerner et al. 2000).

Factors frequently related to forest recovery, or land abandonment leading to forest recovery, are slope, soil productivity or fertility, distance from roads, and distance from pre-existing forest. Steeper slopes and unproductive soils appear to maintain forest cover or enhance forest recovery (Flinn et al. 2005; Mitsuda and Ito 2011; Lieskovsky et al. 2015), and forest recovery or land abandonment is more likely to occur far from roads (Flinn et al. 2005; Mitsuda and Ito 2011; Schweizer and Matlack 2014). Forest recovery has also mostly occurred closer to preexisting forest (Crk et al. 2009; Wulf et al. 2010; Puddu et al. 2012). Among studies that quantified the amount of variability of LULC or LULC change explained by different drivers, along with the pure and joint effects of each group of drivers (Van Doorn and Bakker 2007; Wulf et al. 2016), none have included the effect of distance from pre-existing forest. In this paper, we quantified the additive effects of three types of drivers (biophysical, socioeconomic and distance from pre-existing forest) to disentangle their pure and joint effects.

The Mediterranean region is characterised by strong biophysical constraints compared to temperate regions: water limitations due to hot and dry summers and a hard calcareous substrate with a high stone content result in a specific agriculture (vineyards, olive trees, lavender). A rugged topography led farmers to 
cultivate slopes, resulting in the traditional Mediterranean landscape characterised by terraced crops and extensive grazing. Studying Mediterranean landscapes is thus of particularly interest when seeking to quantify and disentangle the respective effects of drivers of LULC and LULC change. Also, drivers of LULC and forest recovery may differ in the Mediterranean region compared to temperate or lowland regions, where biophysical and socio-historical contexts are different.

Since current landscapes result from very long-term changes (Foley et al. 2005), access to LULC data dating back more than only a few decades is of crucial importance (Bender et al. 2005; Bieling et al. 2013; Wulf et al. 2016). Besides, the effect of former land use on ecosystems can modify forest plant communities and soil properties for centuries (Dupouey et al. 2002). Throughout Europe, the recent availability of precise historical maps dating back to the beginning of the nineteenth century now allows the reconstruction of remote-past landscapes and helps gain a better understanding of long-term change (Kaim et al. 2016). However, drivers of forest cover change have rarely been assessed on both large spatial and temporal scales (more than $1000 \mathrm{~km}^{2}$ and more than 100 years) (but see Flinn et al. 2005; Wulf et al. 2016). Assessing LULC change with more than two dates allows proper quantification of LULC turn-over and identification of temporal discontinuities in LULC change (Zhou et al. 2011). Yet studies of LULC change over a long time span, with a high temporal resolution and over a large spatial extent are very scant (Wulf et al. 2010; De Keersmaeker et al. 2015).

Forest cover dynamics can only be fully understood by combining LULC transitions (where did forest cover come from?) and drivers of forest cover change (why did this transition occur here?). We set out to assess the effect of drivers on forest recovery, and to combine it with the changing effect of drivers on LULC over time. We assessed LULC spatial distribution and forest recovery since 1860 in the Regional Natural Park of Luberon (PNRL), a typical Mediterranean landscape. Firstly, we characterised LULC change and persistence since 1860 by focusing on the four main LULC available at each date: forest, arable land, pasture and built areas. Secondly, we quantified the effects of biophysical and socioeconomic drivers on forest, arable land and pasture in 1860, 1958 and 2010, and the effects of biophysical and socioeconomic drivers and distance from pre-existing forest on forest recovery for the two time intervals. We specifically addressed the following questions:

- At the expense of what LULC did forest recovery take place?

- What biophysical and socioeconomic drivers explain the spatial distribution of LULC and how did their effects change between 1860 and 2010?

- What biophysical, socioeconomic and landscape drivers explain the spatial distribution of forest recovery and how did their effects change between 1860 and 2010 ?

\section{Methods}

Study area

The PNRL is located in the eastern French Mediterranean region $\left(43^{\circ} 39^{\prime} \mathrm{N} 44^{\circ} 02^{\prime} \mathrm{N}, 4^{\circ} 58^{\prime} \mathrm{E} 5^{\circ} 55^{\prime} \mathrm{E}\right)$ and covers 195,413 ha (Fig. 1). The climate is Mediterranean with mild humid winters and hot dry summers (annual mean precipitation $710 \mathrm{~mm}$, mean temperature $13{ }^{\circ} \mathrm{C}$ ) (Varese 1990). Elevation ranges from 51 to $1252 \mathrm{~m}$. The land is mostly calcareous (95\%) except for an acidic substrate strip in its northern part. This rural area is currently composed of 81 small towns (35-4775 inhabitants) and 4 mediumsize towns (12,000-25,000 inhabitants). More than half of the PNRL is now covered by forest $(55 \%)$. Agricultural land supports annual crops (59\%), vineyards (26\%), tree crops (13\%) and meadows (2\%).

Forest transition occurred in Provence during the nineteenth century. Until the mid-nineteenth century the economy of the region was based on an agrosylvo-pastoral system: sheep and goats, bred for wool and milk, roamed in forest and garrigue which served as pasture; their manure and some forest products (boxwood and dead leaves) were used to fertilise crops. Forests were mostly coppiced for firewood, tanning (oak bark) and grazing. The rural population peaked in the period 1830-1860, and forest cover shrank correspondingly (Appendix S1). The economic system was no longer compatible with population growth and economic pressure from the national and regional markets (Chalvet 2006). Administrative laws were enacted in 1860 and 1864 to restore forest cover and curb soil erosion (Fourchy 1963; Gilbert 1989). 


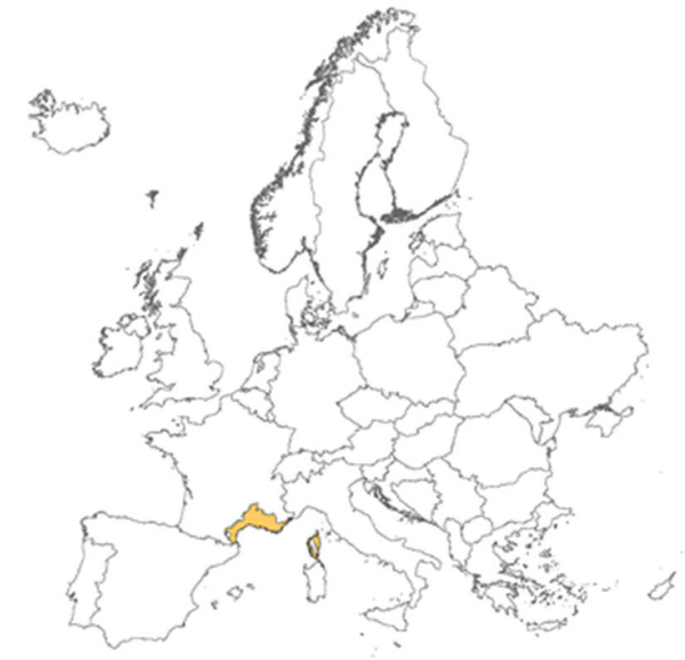

\section{French Mediterranean region}
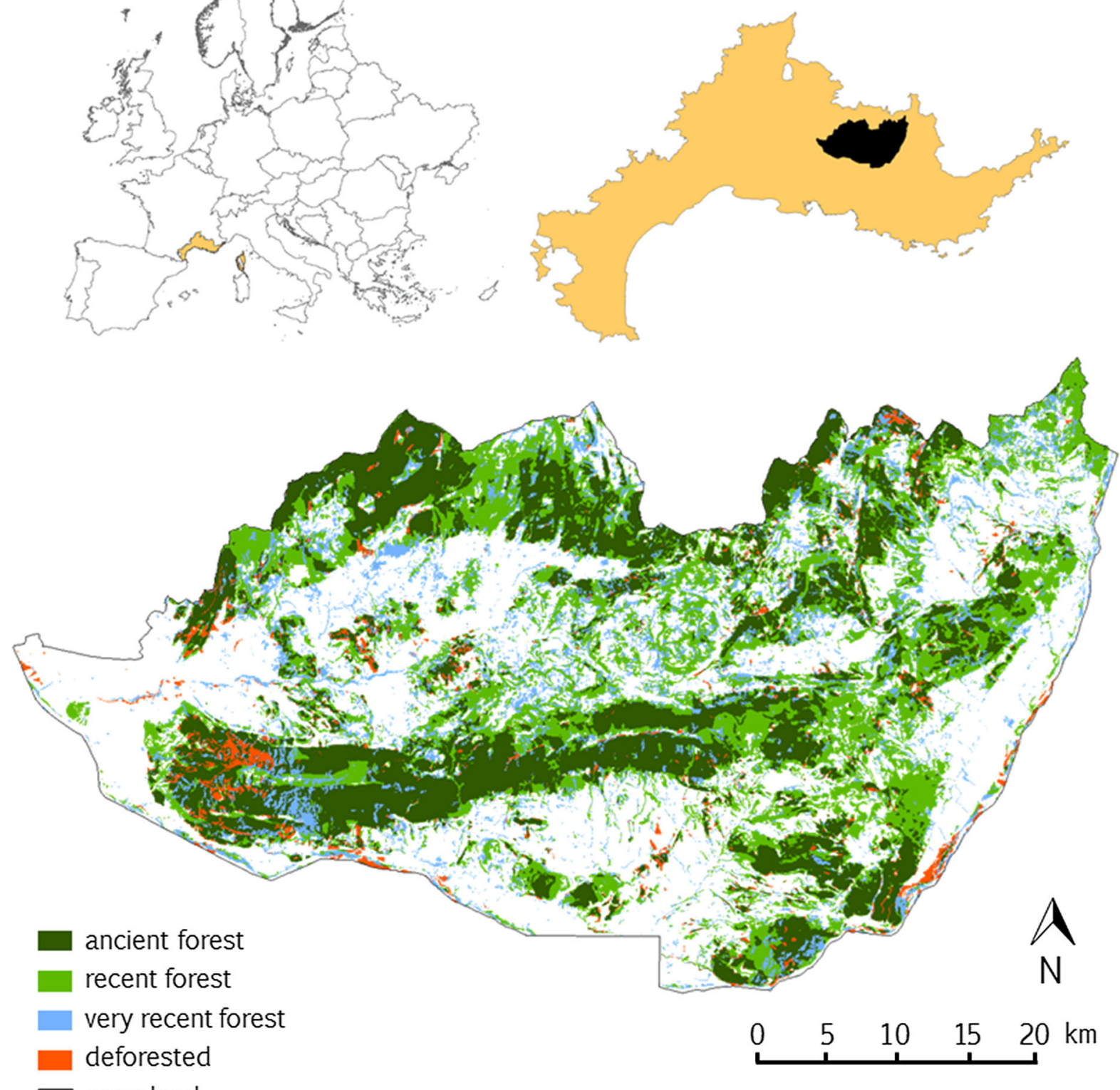
open land

Fig. 1 Study area and forest cover change since 1860. Forest cover change is represented according to 1860,1958 and 2010 forest cover. Ancient forest: persistent since 1860, recent forest:

Forest grazing regulation and the setting-up of a new economic market made pastoralism a less profitable activity, so local farmers and shepherds gradually changed their practices (Chalvet 2006). In this developed between 1860 and 1958, very recent forest: developed between 1958 and 2010, deforested: deforested between 1860 and 2010

context, also characterised by the industrial revolution, the region experienced great rural exodus. Land abandonment allowed forest to recover naturally (monospecific plantations were of minor importance) 
and since the early nineteenth century, forest cover gradually increased (Fig. 2, Appendix S2). The rural population continued to decline during the first half of the twentieth century, partly due to the Great War of 1914-1918 (Appendix S1). After 1960, rural population rose again following 'rurbanisation'. Since then, the tertiary sector has been growing rapidly at the expense of agriculture. In 1977, the PNRL was created with the main objective of reconciling economic development and the preservation of traditional rural activities.

Data

We created a systematic $1000 \times 1000 \mathrm{~m}$ grid of points covering the whole study area (1916 points), and extracted LULC at each date and data for each spatially explicit factor (see Kaim et al. 2016).

\section{LULC maps}

The 1860 LULC map was digitised from the ÉtatMajor map (1858-1861 in the study area) (Salvaudon et al. 2012). The map scale was 1:40,000 and the median position error about $26 \mathrm{~m}$ after georeferencing. LULC in 1958 was photo-interpreted at point scale using 1953 and 1958 aerial orthophotographs. The 2010 LULC map resulted from a combination of contemporary maps [forest cover map (BD Forêt ${ }^{\circledR} \mathrm{v} 2$ ), built area map (BD TOPO ${ }^{\circledR}$ Bâti) and regional land cover]. For all three dates, five land use categories were defined in accordance with the LULCs defined on the État-Major map: forest, arable land, pasture, built area, other. Arable land included all types of crops and hay meadows, while pasture corresponded to garrigue (Mediterranean sclerophyllous scrubland) and pastured grasslands. For further details, see Appendix S3.

\section{Biophysical factors}

Elevation, slope and aspect were extracted from a digital elevation model (DEM) with a resolution of $25 \mathrm{~m}$, retrieved from the French database BD ALTI ${ }^{\circledR}$ (Table 1). Aspect was transformed into northness (the cosine of aspect). Topographic position index (TPI) indicates the relative elevation of a point according to its surrounding environment: above (positive value) or below (negative value). It was derived from the DEM using the Topography Toolbox for ArcGIS 10.3 (Jenness et al. 2013), using a circular neighbourhood method. After testing differing radii (4, 20, 40 and 80 cells), the TPI calculated within a four-cell radius was retained, as this scale explained the higher deviance for all LULCs. We used a 1:50,000 geological vector map (CBRGM French Geological Survey 1998) to assess soil potential productivity for agriculture. The 52 geological formations were simplified into three
Fig. 2 Forest cover change (ha) in Vaucluse and Alpesde-Haute-Provence since 1776. See Appendix S2 for further details on the historical sources used

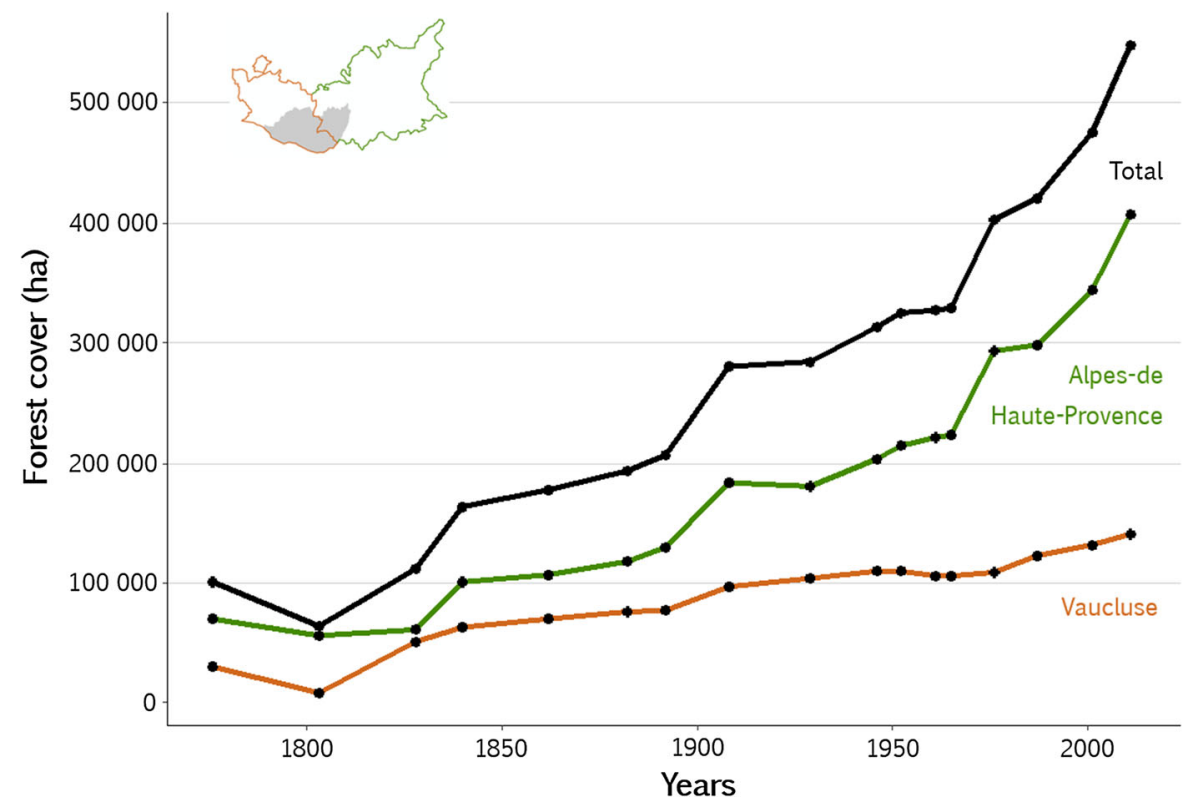


Table 1 Biophysical, socioeconomic factors and distance from pre-existing forest: range, unit, source and date available in 1860, 1958 and 2010

\begin{tabular}{|c|c|c|c|}
\hline Factors & Ranges and units & Sources & $\begin{array}{l}\text { Date } \\
\text { available }\end{array}$ \\
\hline \multicolumn{4}{|l|}{ Biophysical factors } \\
\hline Elevation & 55 to $1210 \mathrm{~m}$ & DEM 25 m (BD ALTI $\left.^{\circledR}\right)$ & \\
\hline Slope & 0 to $98 \%$ & Idem & \\
\hline TPI & -26.2 to $25.9 \mathrm{~m}$ & Idem & \\
\hline Northness & Exposure index -1 (south) to 1 (north) & Idem & \\
\hline Substrate type & Three categories: $44 \%$ loose, $38 \%$ hard and $18 \%$ other & (C)BRGM lithology map & \\
\hline AWC & 0.08 to 0.13 & ESDAC & \\
\hline SAND & 14.2 to $57.3 \%$ & Idem & \\
\hline SILT & 28.4 to $58.4 \%$ & Idem & \\
\hline CLAY & 12.3 to $37.2 \%$ & Idem & \\
\hline COARSE.F & 6.7 to $36.9 \%$ & Idem & \\
\hline D.RIVER & 0.8 to $7294 \mathrm{~m}$ & 2013 BD Carthage ${ }^{\circledR}$ map & \\
\hline \multicolumn{4}{|l|}{ Socioeconomic factors } \\
\hline POP.DENS & $\begin{array}{l}\text { 1861: } 5 \text { to } 163.1 \text { inhab } \mathrm{km}^{-2}, 1954: 1.7 \text { to } 323.4 \text { inhab } \mathrm{km}^{-2} \text {, } \\
\text { 2012: } 1.6 \text { to } 551.4 \text { inhab km }\end{array}$ & Archives and INSEE & $\begin{array}{c}1861 \\
1954, \\
2012\end{array}$ \\
\hline FARMER.DENS & $\begin{array}{l}\text { 1851: } 4.2 \text { to } 58 \text { inhab } \mathrm{km}^{-2}, 1968: 0 \text { to } 23.7 \text { inhab } \mathrm{km}^{-2} \text {, } \\
\text { 1999: } 0 \text { to } 11.6 \text { inhab km } \mathrm{km}^{-2}\end{array}$ & Idem & $\begin{array}{c}1851 \\
1968, \\
1999\end{array}$ \\
\hline D.HOUSE & 1860: 0 to $2414 \mathrm{~m}, 1958: 0$ to $2598 \mathrm{~m}, 2010: 0$ to $2697 \mathrm{~m}$ & $\begin{array}{l}\text { 1860, } 1958 \text { and } 2010 \text { land use } \\
\text { map (built area) }\end{array}$ & $\begin{array}{c}1860 \\
1958 \\
2010\end{array}$ \\
\hline D.ROAD & 1860: 1 to $7225 \mathrm{~m}, 1958: 0$ to $2860 \mathrm{~m}, 2010: 0$ to $2642 \mathrm{~m}$ & $\begin{array}{l}1860 \text { and } 1958 \text { road maps, } \\
2009 \text { BD Route }{ }^{\circledR}\end{array}$ & $\begin{array}{c}1860 \\
1958 \\
2009\end{array}$ \\
\hline D.CENTRE & 41.2 to $10,300 \mathrm{~m}$ & Town centre & \\
\hline ELE.DIFF & -294 to $789 \mathrm{~m}$ & DEM $25 \mathrm{~m}$ & \\
\hline D.CANAL & 0.1 to $19,060 \mathrm{~m}$ & 2013 BD Carthage ${ }^{\circledR}$ map & \\
\hline D.PREEX.FOREST & 1958: 0 to $3174 \mathrm{~m}, 2010: 0$ to $3209 \mathrm{~m}$ & 1860 and 1958 land use maps & 1860,1958 \\
\hline
\end{tabular}

groups according to their potential agricultural productivity: loose substrates (alluvial and colluvial deposits, molasse), hard substrates (hard limestone and conglomerates) and other substrates (acidic, marl and clay soils). We also used physical characteristics of topsoil (top $20 \mathrm{~cm}$ ) from the European Soil Data Centre (ESDAC, http://esdac.jrc.ec.europa.eu/; Panagos et al. 2012) with a resolution of $500 \mathrm{~m}$ : available water capacity (AWC), sand, silt, clay and coarse fragment content (COARSE.F) (Ballabio et al. 2016). Finally, we retrieved the natural waterway network from the BD Carthage ${ }^{\circledR} 2013$ (http://professionnels. ign.fr/bdcarthage), keeping only the main rivers, and then calculated the distance from the nearest river
(D.RIVER). Biophysical factors were assumed to be stable throughout the study period.

\section{Socioeconomic factors}

We retrieved the 1861 communal population and 1851 farmer population figures from the departmental archives (http://archives.vaucluse.fr; http://www. archives04.fr) and 1954 and 2012 communal population and 1968 and 1999 farmer population figures from the National Institute of Statistics and Economic Studies (INSEE, https://www.insee.fr). Communal population density and farmer density (POP.DENS and FARMER.DENS, respectively) were obtained 
from the census data for each municipality divided by the municipal area (stable throughout the study period). To assess the effect of distance from transport infrastructure (D.ROAD) or houses (D.HOUSE), we used the main road network and the built area cover at each date (see sources in Table 1). We also examined distance from town centre (D.CENTRE), elevation difference with town centre (ELE.DIFF) and distance from the nearest canal (D.CANAL). For each point, the town centre corresponded to the old village part of its municipality and was extracted from the 1860 LULC map. The canal network was retrieved from the BD Carthage ${ }^{\circledR}$ 2013. Distance variables were the Euclidean distance between each point and the nearest edge of the focal object on the corresponding map. Socioeconomic factors corresponded to the data available closest to each date, except for town centre and canal network, assumed to be stable throughout the study period (Table 1).

Finally, we calculated the distance from the nearest pre-existing forest edge from LULC maps, and only tested its effect on forest recovery.

\section{Analysis}

LULC transitions were obtained by crossing 1860 , 1958 and 2010 LULC at point scale and synthesised in a transition matrix that quantified total gain and loss, net change and persistence, and the past and next transitions of each LULC (Pontius et al. 2004). We converted the transition matrix into a transition diagram, following Cousins (2001).

The effect of all the drivers on LULC and forest recovery was assessed by logistic regressions (Van Doorn and Bakker 2007; Schweizer and Matlack 2014): we fitted models of LULC or forest recovery as a smooth function of the different drivers in a generalised additive model (GAM) with the R package $m g c v$ (Wood 2006) using a logit link function. To take into account spatial autocorrelation in our models (Beale et al. 2010; Saas and Gosselin 2014), we incorporated spatial effects as covariates using a smooth function of geographical coordinates (UTM northing and easting), as proposed by Eitzel et al. (2016). A Moran test was applied to assess the global autocorrelation in the model residuals using the $\mathrm{R}$ package spdep (Bivand 2013); we defined point neighbourhood by Euclidean distance using a binary neighbours list and a maximal threshold distance of 2000 m (Appendix S4).

First, we ran nine models to analyse the effect of biophysical and socioeconomic factors on forest, arable land and pasture in 1860, 1958 and 2010, as they were the most important land uses in terms of area covered and economic interest. Demographic data were log-transformed, and distance data were square root-transformed before analysis to respect normality. Second, we analysed the effect of biophysical and socioeconomic factors and distance from pre-existing forest on forest recovery between 1860 and 1958 using the 1400 points not located in forest in 1860, and between 1958 and 2010 using the 1115 points not located in forest in 1958.

For each LULC at each date, each predictor was tested independently with a univariate model, then a multiple regression was performed using all the significant predictors (full model); if two predictors were correlated $(R>0.6)$, only the one explaining a higher deviance was included in the full model and the other was dropped (Appendix S5). Then, a parsimonious final model was obtained by sequentially dropping the single term with the highest non-significant $p$ value from the full model and re-fitting the model until only significant predictors remained. Model fit was followed by deviance partitioning to determine pure and joint effects of each group of predictors (Van Doorn and Bakker 2007): biophysical, socioeconomic and spatial factors for the nine land use models, and biophysical, socioeconomic, spatial factors and distance from pre-existing forest for the two forest recovery models (Appendix S6). As elevation difference with town centre could be considered as a biophysical as well as a socioeconomic factor, we averaged the two decomposition models with the variable considered first as a biophysical and then as a socioeconomic factor.

All the mapping data were processed using ArcGIS 10.3; statistical analysis was carried out using $\mathrm{R}$ software v. 3.2.5 (R Core Team 2016).

\section{Results}

LULC transitions

In 1860, forest, arable land and pasture were the three main LULCs and arable land was predominant, while 
in 2010, forest became predominant and pasture was no longer a main LULC (Fig. 3). Forest and built-up area increased continuously from 1860 to $2010(+103$ and $+664 \%$, respectively), while arable land and pasture showed a continuous decrease $(-31$ and $-72 \%$, respectively). Over the whole period, $16.3 \%$ of 1860 forest was lost and $46 \%$ of the total area experienced at least one LULC change involving one of the five categories, with 30 and $23 \%$ of global LULC change between 1860 and 1958, and between 1958 and 2010, respectively (Table S7-4). Forest, arable land and pasture persistence since 1860 constituted 84,59 and $3 \%$ of their original cover, respectively (Fig. 3; Table S7-3). In 1958, 56\% of the forest cover originated from forest present in 1860, $27 \%$ from pasture and $16 \%$ from arable land. In 2010, 74\% of the forest cover came from forest present in 1958, $12 \%$ from arable land and $13 \%$ from pasture. About $79 \%$ of 1860 pasture was reforested in 2010 , and $28 \%$ of 1860 arable land was reforested in 2010 . To a lesser extent, arable land was turned into pasture $(5 \%$, mostly between 1958 and 2010) or built area (7\%, mostly between 1958 and 2010, Table S7-4). Annual forest recovery rate was $0.45 \%$ in the first period (1860-1958) and $0.51 \%$ in the second one (1958-2010).
Drivers of LULC and forest recovery

Spatial autocorrelation in the model residuals was never significant for the threshold distance retained (Appendix S4) and the 11 models tested. The spatial term was always significant (Tables 2, 3).

Forest, arable land and pasture in 1860, 1958 and 2010

Slope, TPI, substrate type and D.HOUSE were the main drivers of LULC at each date (Table 2). Elevation had no effect on the presence of arable land, but influenced pasture in 1860 and 1958, and forest in 2010: both pasture and forest frequencies increased on higher land (Fig. S8-1). Forest frequency was higher on steeper slopes in 1860, and reached an optimum for slopes between 30 and $45 \%$ from 1958 onwards; pasture frequency was higher on intermediate and steep slopes (from 20\%) and arable land frequency decreased with increasing slope (Fig. S8-2). According to $\chi^{2}$ values, the effect of slope on forest and arable land frequency increased gradually from 1860 to 2010, but decreased for pasture. Arable land was always more frequent on flat topography $(\mathrm{TPI}=0)$, pasture on convex topography (TPI $>0$ ), and forest on
Fig. 3 LULC transition from 1860 to 2010. Each LULC area at given date is represented by a proportional square. Persistence is represented by a darker square included in the total area square. Arrows represent percentage of LULC change regarding forest between 1860 and 1958 (or between 1958 and 2010), relative to the total amount of forest in 1958 (or 2010). For clarity, other LULC trajectories were not represented. The number of points of each LULC at each date is reported under each square and the number of points of transitions is reported above the corresponding arrow

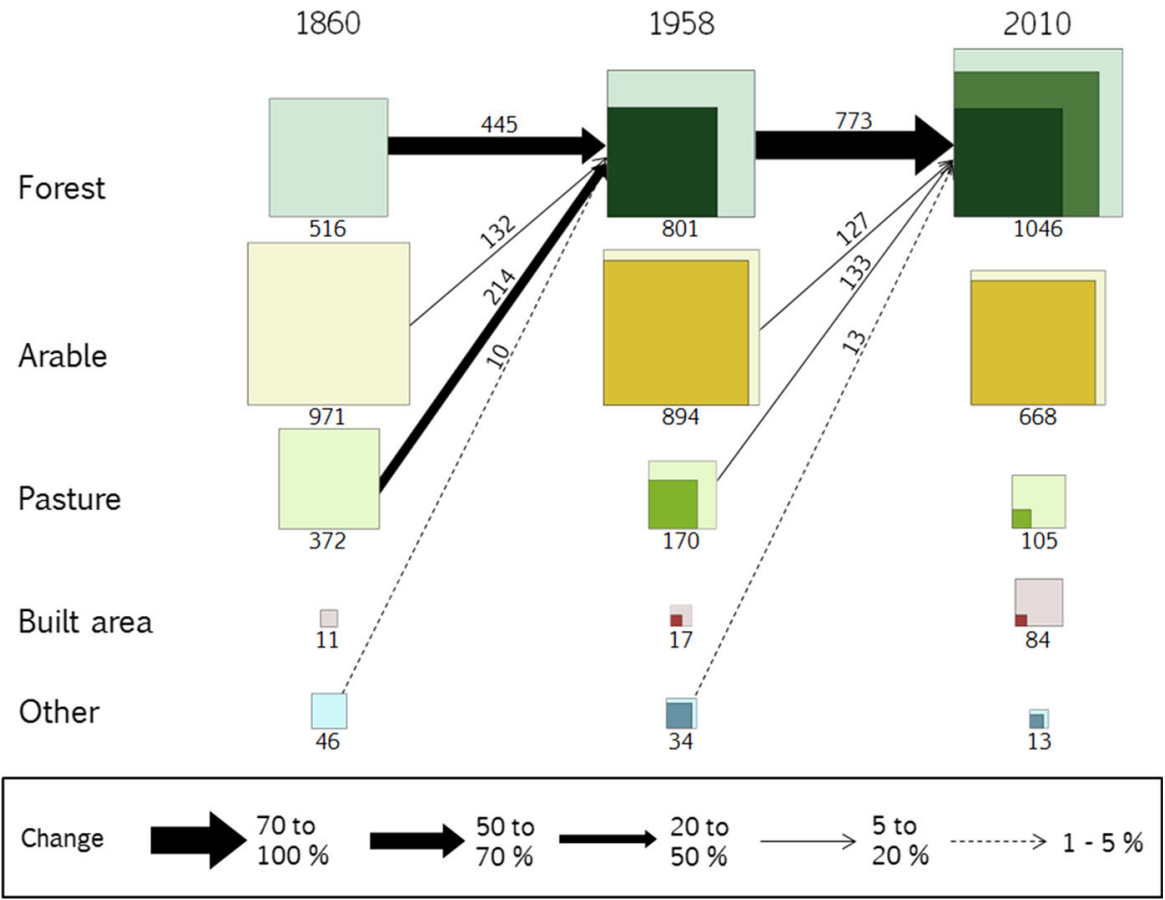


Table 2 Final GAM models for major LULCs (forest, arable and pasture) at each date, and deviance partitioning (\%)

\begin{tabular}{|c|c|c|c|c|c|c|c|c|c|}
\hline & \multicolumn{3}{|l|}{1860} & \multicolumn{3}{|l|}{1958} & \multicolumn{3}{|l|}{2010} \\
\hline & Forest & Arable & Pasture & Forest & Arable & Pasture & Forest & Arable & Pasture \\
\hline LULC frequency & 0.27 & 0.51 & 0.19 & 0.42 & 0.47 & 0.09 & 0.55 & 0.35 & 0.05 \\
\hline \multicolumn{10}{|c|}{ Significance and direction of effects } \\
\hline \multicolumn{10}{|l|}{ Biophysical factors } \\
\hline Elevation & - & - & $6^{*}(+)$ & - & - & $16^{*}(+)$ & $20 * * *(+)$ & - & - \\
\hline Slope & $\begin{array}{c}29 * * * \\
(+)\end{array}$ & $\begin{array}{c}61 * * * \\
(-)\end{array}$ & $\begin{array}{c}36 * * * \\
(+)\end{array}$ & $\begin{array}{r}81 * * * \\
(\text { opt })\end{array}$ & $\begin{array}{c}102 * * * \\
(-)\end{array}$ & $\begin{array}{r}16 * * \\
(+)\end{array}$ & $\begin{array}{c}138 * * * \\
\text { (opt) }\end{array}$ & $\begin{array}{c}136 * * * \\
(-)\end{array}$ & - \\
\hline TPI & - & $\begin{array}{r}25 * * * \\
(\text { opt })\end{array}$ & $7 * *(+)$ & $\begin{array}{c}35 * * * \\
(-)\end{array}$ & $\begin{array}{r}48 * * * \\
(\mathrm{opt})\end{array}$ & $\begin{array}{r}12 * * \\
(+)\end{array}$ & $18 * *(-)$ & $\begin{array}{r}27 * * * \\
(\text { opt })\end{array}$ & - \\
\hline Substrate type & $26 * * *$ & $38 * * *$ & $27 * * *$ & $20 * * *$ & $28 * * *$ & - & $17 * * *$ & $14 * * *$ & - \\
\hline COARSE.F & $\begin{array}{c}17 * * * \\
(+)\end{array}$ & - & - & $\begin{array}{c}19 * * * \\
(+)\end{array}$ & $9 * *(-)$ & - & $18 * * *(+)$ & - & - \\
\hline SAND & $\begin{array}{l}13^{*} \\
\text { (opt) }\end{array}$ & - & - & - & - & - & - & - & - \\
\hline D.RIVER & - & $7 * *(+)$ & - & - & $\begin{array}{c}31 * * * \\
(+)\end{array}$ & - & $32 * * *(-)$ & $\begin{array}{c}35 * * * \\
(+)\end{array}$ & $\begin{array}{c}29 * * * \\
(-)\end{array}$ \\
\hline \multicolumn{10}{|l|}{ Socioeconomic factors } \\
\hline D.ROAD & $9 * *(+)$ & $\begin{array}{c}15 * * * \\
(-)\end{array}$ & - & - & - & - & - & - & - \\
\hline D.HOUSE & $\begin{array}{c}60 * * * \\
(+)\end{array}$ & $\begin{array}{c}137 * * * \\
(-)\end{array}$ & $\begin{array}{r}37 * * * \\
\text { (opt) }\end{array}$ & $\begin{array}{c}101 * * * \\
(+)\end{array}$ & $\begin{array}{c}191 * * * \\
(-)\end{array}$ & - & $99 * * *(+)$ & $\begin{array}{c}176 * * * \\
(-)\end{array}$ & - \\
\hline D.CENTRE & $\begin{array}{c}23 * * * \\
(+)\end{array}$ & $\begin{array}{c}20 * * * \\
(-)\end{array}$ & - & $7 * *(+)$ & - & - & - & - & - \\
\hline ELE.DIFF & $9 *(+)$ & $10 *(-)$ & - & $9 *(+)$ & $8 * *(-)$ & - & $7 *(+)$ & $\begin{array}{c}17 * * * \\
(-)\end{array}$ & - \\
\hline Spatial term & $180 * * *$ & $99 * * *$ & $193 * * *$ & $136 * * *$ & $67 * * *$ & $146 * * *$ & $17 *$ & $49 * * *$ & $40 * * *$ \\
\hline \multicolumn{10}{|l|}{ Deviance partitioning } \\
\hline $\mathrm{PE}(\mathrm{BIO})$ & 4.65 & 5.45 & 4.10 & 8.95 & 14.20 & 5.20 & 10.15 & 13.95 & 2.55 \\
\hline $\mathrm{PE}(\mathrm{SOC})$ & 5.05 & 5.25 & 2.40 & 4.20 & 6.20 & 0.00 & 2.50 & 9.60 & 0.00 \\
\hline PE(SPA) & 11.90 & 4.90 & 14.00 & 7.90 & 3.10 & 17.70 & 1.20 & 2.90 & 7.00 \\
\hline $\mathrm{JE}(\mathrm{BIO}, \mathrm{SOC})$ & 2.90 & 3.20 & -0.10 & 3.75 & 3.90 & 0.00 & 3.85 & -0.25 & 0.00 \\
\hline $\mathrm{JE}(\mathrm{BIO}, \mathrm{SPA})$ & 5.40 & 6.75 & 6.36 & 4.15 & 3.20 & 6.50 & 9.00 & 5.25 & 1.55 \\
\hline $\mathrm{JE}(\mathrm{SOC}, \mathrm{SPA})$ & 3.85 & 5.60 & 0.70 & 2.80 & 4.35 & 0.00 & 1.95 & 1.95 & 0.00 \\
\hline JE(BIO, SOC, SPA) & 15.85 & 13.15 & 0.74 & 16.35 & 20.05 & 0.00 & 18.05 & 15.10 & 0.00 \\
\hline $\begin{array}{l}\text { Total explained } \\
\text { deviance }\end{array}$ & 49.60 & 44.30 & 28.20 & 48.10 & 55.00 & 29.40 & 46.70 & 48.50 & 11.10 \\
\hline
\end{tabular}

The table gives $\chi^{2}$ values of each predictor in the final model and total deviance explained (\%) for each model used for the deviance partitioning. All models were applied on 1916 points. Significance of the relation are provided by stars reflecting $\mathrm{p}$ values: $0<* * *<$ $0.001<* *<0.01<*<0.05$. Northness, AWC, POP.DENS, FARMER.DENS and D.CANAL were tested, but were not significant. The direction of the relation between each LULC and each predictor is given by + (positive relation), - (negative relation) and 'opt' (optimum at intermediate values). See Appendix S8 for detailed relations. All other lines correspond to the joint effect (JE) of the different combinations of these groups of factors

$P E(B I O)$ pure effect of biophysical factors, $P E(S O C)$ pure effect of socioeconomic factors, $P E(S P A)$ pure effect of spatial factor

concave topography (TPI $<0$; Table 2; Fig. S8-3). Globally, forest was more frequent on hard substrates and less frequent on loose substrates at each date, whereas arable land showed the opposite pattern, and pasture was more often present on other substrates in 1860 (Fig. 4). The effect of substrate type on forest and arable land decreased gradually from 1860 to 2010, and was non-significant for pasture in 1958 and 
Table 3 Final GAM models for forest recovery from 1860 to 1958 (1400 points) and from 1958 to 2010 (1115 points), and deviance partitioning $(\%)$

\begin{tabular}{|c|c|c|}
\hline & \multicolumn{2}{|c|}{ Forest recovery } \\
\hline & $1860-1958$ & $1958-2010$ \\
\hline Forest recovery frequency & 0.25 & 0.24 \\
\hline \multicolumn{3}{|c|}{ Significance and direction of effects } \\
\hline \multicolumn{3}{|l|}{ Biophysical factors } \\
\hline Slope & $97 * * *$ & $56 * * *$ \\
\hline Substrate type & $25 * * *$ & - \\
\hline COARSE.F & $6 *$ & - \\
\hline \multicolumn{3}{|l|}{ Socioeconomic factors } \\
\hline D.HOUSE & $61 * * *$ & $24 * * *$ \\
\hline D.PREEX.FORESTS & $32 * * *$ & $60 * * *$ \\
\hline Spatial term & $74 * * *$ & $14 * * *$ \\
\hline \multicolumn{3}{|l|}{ Deviance partitioning } \\
\hline $\mathrm{PE}(\mathrm{BIO})$ & 10.50 & 3.40 \\
\hline $\mathrm{PE}(\mathrm{SOC})$ & 3.80 & 1.80 \\
\hline PE(D.FOR) & 2.30 & 4.70 \\
\hline PE(SPA) & 7.00 & 1.50 \\
\hline $\mathrm{JE}(\mathrm{BIO}, \mathrm{SOC})$ & -0.10 & -0.30 \\
\hline JE(BIO, D.FOR) & 1.30 & 3.90 \\
\hline JE(SOC, D.FOR) & 0.50 & 1.20 \\
\hline JE(BIO, SPA) & 4.80 & 2.70 \\
\hline JE(SOC, SPA) & 0.70 & 0.70 \\
\hline JE(D.FOR, SPA) & 0.20 & 0.50 \\
\hline JE(BIO, SOC, D.FOR) & 0.20 & -0.10 \\
\hline JE(BIO, SOC, SPA) & 2.25 & 0.00 \\
\hline JE(BIO, D.FOR, SPA) & 5.05 & 11.00 \\
\hline JE(SOC, D.FOR, SPA) & -0.10 & 1.50 \\
\hline JE(BIO, SOC, D.FOR, SPA) & -0.60 & 0.60 \\
\hline Total explained deviance & 37.80 & 33.10 \\
\hline
\end{tabular}

The table gives $\chi^{2}$ values of each predictor in the final model and total deviance explained (\%) for each model used for the deviance partitioning. Significance of the relation are provided by stars reflecting p values: $0<* * *<0.001<* *<0.01<*<$ 0.05. Elevation, northness, TPI, AWC, SAND, D.RIVER, D.ROAD, D.CENTRE, POP.DENS, FARMER.DENS, ELE.DIFF and D.CANAL were tested, but were not significant. All other lines correspond to the joint effect (JE) of the different combinations of these groups of factors

$P E(B I O)$ pure effect of biophysical factors, $P E(S O C)$ pure effect of socioeconomic factors, $P E(D . F O R)$ pure effect of distance from pre-existing forest, $P E(S P A)$ pure effect of spatial factor

2010. COARSE.F had an effect at each date on forest location only: forest mostly occurred on soils with higher COARSE.F (Table 2; Fig. S8-4). Forest occurrence increased farther from houses up to 600 to $1000 \mathrm{~m}$; arable land occurrence was maximal at $50 \mathrm{~m}$ from houses and then decreased with distance from houses (Fig. S8-5), and this pattern became more pronounced in 1958 and 2010. In 1860, pasture occurrence peaked at $100-600 \mathrm{~m}$ from houses, but was not influenced by distance from houses after this date. Globally, forest had higher elevation than town centre, whereas arable land decreased with ELE.DIFF (Fig. S8-6).

The forest and arable land models in 1860, 1958 and 2010 globally explained between 44 and $55 \%$ of the total deviance. The pasture models explained $28 \%$ of the total deviance in 1860 but only $11 \%$ in 2010 (Table 2). From 1860 to 2010, the ratio of the pure effects of biophysical drivers to the pure effect of socioeconomic drivers strongly increased for forest (from 0.9 to 4.1), slightly rose for arable land (from 1 to 1.5), and soared for pasture (from 1.7 to no significant effect of socioeconomic factors). The joint effect of biophysical, socioeconomic and spatial factors (for the three land uses and for each date) was always higher than the pure effect of any group of factors, except for pasture. The pure effect of the spatial factor on each LULC decreased from 1860 to 2010.

\section{Forest recovery}

Forest recovery from 1860 to 1958 depended on slope, substrate type, soil COARSE.F, and distance from houses and from pre-existing forest (Table 3): it occurred more frequently on slopes between 35 and $40 \%$, on soils with higher COARSE.F, mostly marls and clays, farther from houses, and closer to the 1860 forest edge (Fig. 5). Forest recovery from 1958 to 2010 depended on slope, distance from houses and from preexisting forest, but was not influenced anymore by COARSE.F and substrate type: it increased with increasing slope, with a local peak around $40 \%$, peaked around $500 \mathrm{~m}$ from houses and increased with proximity to 1958 forest edge (Fig. 5). Slope and distance from houses had a stronger effect on forest recovery during the first period (1860-1958) than during the second one (1958-2010), while proximity to preexisting forest displayed the reverse trend.

The models of forest recovery explained a similar proportion of deviance for the two periods (38 and $33 \%$ ). During the first period, the pure effect of biophysical factors was predominant (at least twice as 
Fig. 4 Proportion of the five LULCs on different substrates (loose, hard and other substrates) in 1860 , 1958 and 2010

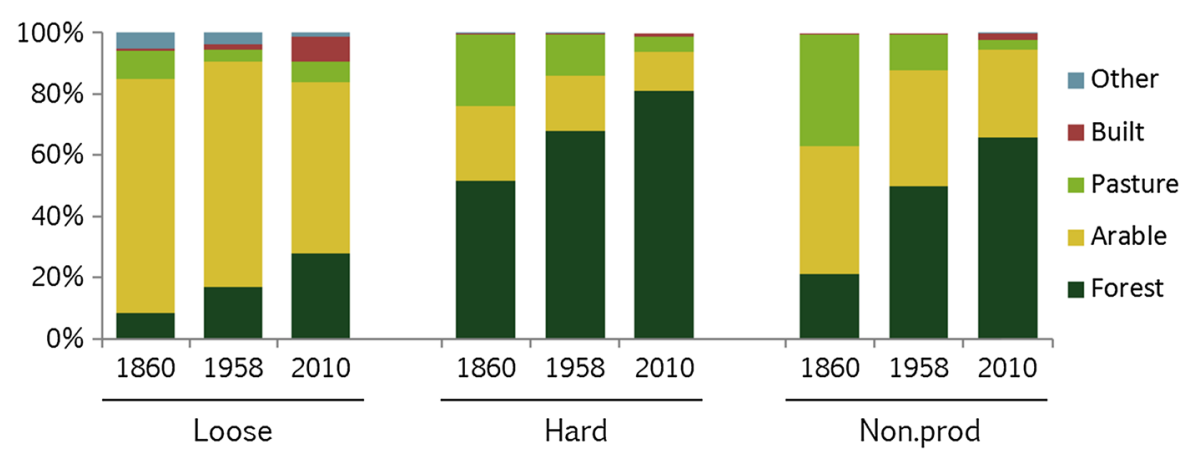

much as the other pure or joint effects). During the second period, the joint effect of biophysical, distance from pre-existing forest and spatial factors became predominant; and the pure effect of distance from preexisting forest was higher than biophysical and socioeconomic pure effects. We note that all the terms including biophysical and socioeconomic factors (pure and joint effects) decreased and all the terms including distance from pre-existing forest (pure and joint effects) increased between the first and the second period.

\section{Discussion}

The doubling of forest cover and the very low rate of deforestation over the whole period confirmed the forest recovery context in the northern Mediterranean region (Nogues-Bravo 2006; Falcucci et al. 2007; Puddu et al. 2012). The overall LULC transformation (46\% over 150 years) echoes the huge proportion of land degradation or transformation reported at the world scale (Antrop 2005; Kareiva et al. 2007). An even lower rate of LULC persistence could be found with a higher time resolution, as demonstrated by De Keersmaeker et al. (2015) for ancient forest rate. Yet, the reconstruction of the forest area since 1776 in our study area (Fig. 2) indicated that no period of net forest loss occurred since 1860 , which means that a reversal of trend was very unlikely to happen between 1860 and 2010. Also, the accuracy of the historical and current map may differ due to position errors (Vuorela et al. 2002; Leyk et al. 2006) but these problems were reduced as far as possible by applying a precise georeferencing correction protocol (Appendix S3). However, we must keep in mind that the État-Major map was based on land uses, while 1958 and 2010 maps were based on land covers, thus pastures or forests in 1860 might not look the same as in 1958 and 2010. This difference in data transcription between ancient and recent sources, the potential limited precision in historical georeferencing and the unknown minimum mapping unit in these historical maps strongly suggest that ancient land use maps must be analysed with caution.

LULC distribution structured by land accessibility and productivity

Between 1860 and 2010, forest, arable land and pasture were mostly structured by slope, topography position, substrate type and distance from the nearest house, reflecting a spatial distribution that depended on land accessibility and soil productivity. Forests were confined to less productive land (steeper slopes, hard substrates, and soils with large amounts of coarse fragments), and less accessible land (far from houses), while arable land subsisted on the sites that were the most productive (flat terrain and loose substrates) and accessible (near houses). Pastures were preferentially located on unproductive land and with either intermediate or limited accessibility. Our study confirms the major role of slope and soil productivity on LULC and especially on forest cover (Mitsuda and Ito 2011; Sandel and Svenning 2013; Lieskovsky et al. 2015). Steep slopes require more effort to work on the land (human force, agricultural equipment). Also, the productivity of soils with high nutrient availability (most PNRL soils) depends mainly on their physical properties: loose substrates such as alluvial or colluvial deposits are much easier to till and are associated with deep soils, unlike hard substrates such as conglomerates and hard limestone ("karst" systems provide very shallow soils). Land accessibility was 

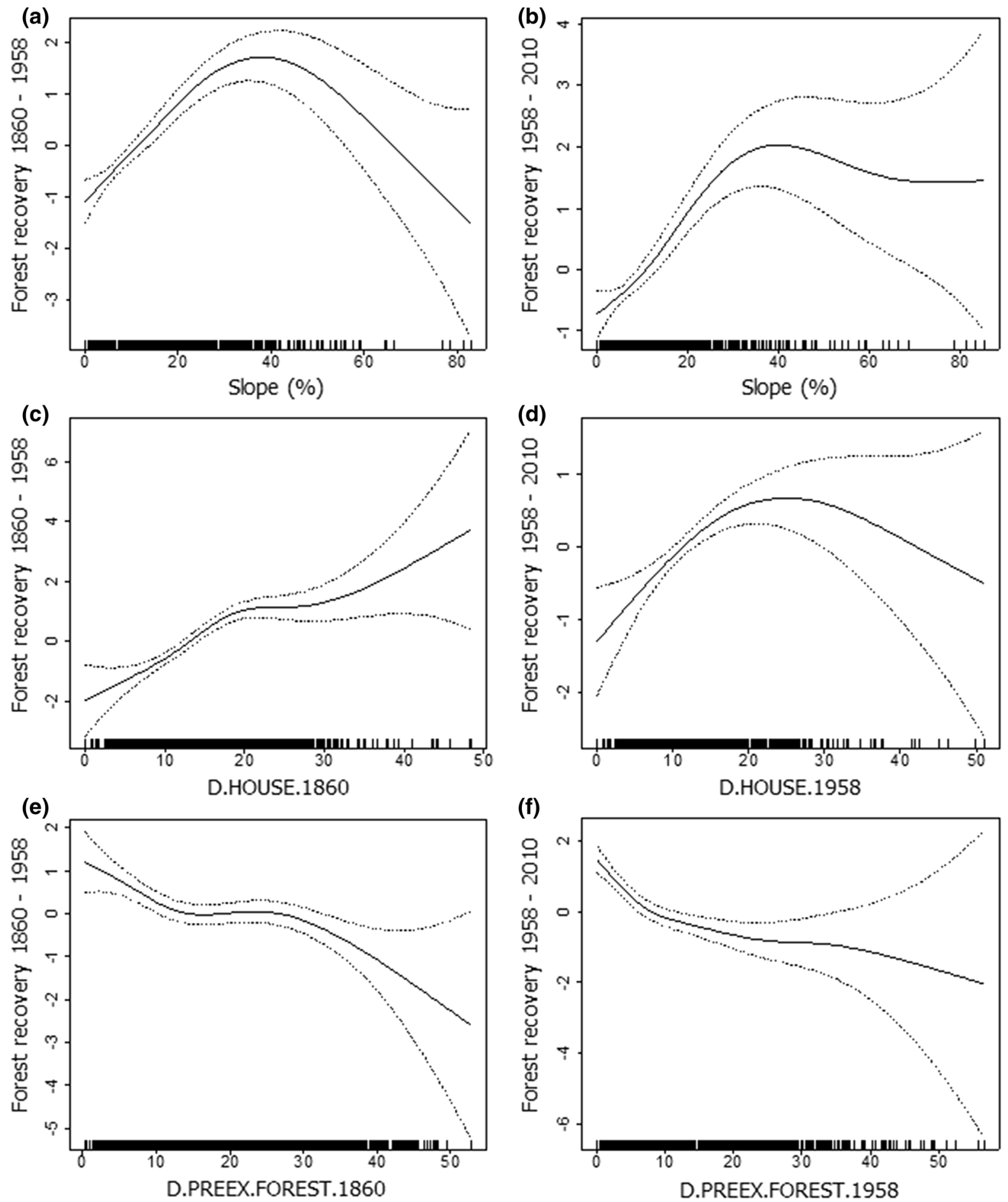

Fig. 5 Univariate smoothed terms of slope, distance from houses and distance from pre-existing forest in relation to forest recovery from 1860 to 1958 (a, c, e) and from 1958 to 2010 (b, d, f). Estimates are shown by solid lines, confidence intervals are

shown by dashed lines. Points are plotted at their location along the base of the graph. Distance to house (D.HOUSE) and distance from pre-existing forest (D.PREEX.FOREST) were square-root transformed (original distances are in meters) 
reflected by distance from houses, but not by distance from roads like elsewhere (Flinn et al. 2005; Mitsuda and Ito 2011). In our study, distance from roads and distance from houses were correlated, and only the effect of the second was retained in the final model. Hence, forests were confined to remote and unproductive areas, where agricultural pressure is likely to have remained nil and which may never have been deforested in the past.

Our results emphasise that socioeconomic and biophysical drivers had an additive effect on LULC spatial distribution. However, their joint effect represented a substantial share of the deviance explained by the statistical models at all three dates, confirming the intertwining of these two groups of drivers (Mitsuda and Ito 2011). A large part of the variability was not explained by the LULC drivers selected. Technological, other economic and political drivers (development of industry, global trading, etc.) together with the human cultural environment and prerequisites (beliefs, knowledge, attitudes, age, health Bürgi et al. 2004) may be responsible for the unexplained part of LULC, but they were not included in our study because difficult to obtain or spatialize. Moreover, some drivers act at a national or international scale, and assessing them would require a study with a much broader scope, as demonstrated at the world scale by Sandel and Svenning (2013).

\section{Abandonment of traditional agriculture} and pastoralism led to forest recovery

Forest recovered mostly at the expense of arable land and pasture, as a consequence of their abandonment, exemplifying the regional (Taillefumier and Piegay 2003; Fabre and Vernet 2006) and Mediterranean trend (Nogues-Bravo 2006; Falcucci et al. 2007; Sereda and Lukan 2009). Our study area suffered from a dramatic abandonment of pasture after 1860, mostly occurring in the first period (1860-1958), while arable land gradually decreased during the two periods. Forest recovery from arable land and pasture resulted from (i) socioecological feedback, and (ii) socioeconomic exogenous drivers (Lambin and Meyfroidt 2010):

(i) The drastic reduction in forest cover in the eighteenth century led to land erosion, and resulted in the implementation of forest protection policy and forest grazing regulation (1860, 1864 and 1882 reforestation laws) and financial incentives to restore forests (Fourchy 1963; Chalvet 2006). At the same time, the agricultural crisis caused the end of sericulture and madder growing, together with a temporary agricultural shrinkage due to the Phylloxera crisis. All this led to outward migration, as indicated by the decline in rural population registered during the first period (Appendix S1).

(ii) The political and economic context reinforced forest management and agricultural practices focused on productivity. The improvement of agricultural yields reduced the need for arable land, and enabled farmers to feed their herds with fodder from meadows and crops, and thus abandon pastoral use of forest, garrigue and grassland (Gilbert 1989), as also observed in Germany (Bieling et al. 2013).

Such LULC change drivers are common in the northern Mediterranean area (Nogues-Bravo 2006; Falcucci et al. 2007; Sereda and Lukan 2009), but in the southern Mediterranean where droughts can be very frequent, climate may be a major driver of LULC change (Nash et al. 2008).

Forest cover increased at the expense of the pasture and arable land located on the steeper slopes, consistent with the global trend (Van Doorn and Bakker 2007; Sereda and Lukan 2009; Schweizer and Matlack 2014; Lieskovsky et al. 2015). Globally, forest is reported to recover preferentially on less productive, formerly cultivated soils (Flinn et al. 2005; Wulf et al. 2010; Schweizer and Matlack 2014). Here, forest significantly recovered on unproductive soils in the first period, but as it recovered on arable land and close to rivers in the second period, it also became frequent on productive soils, and substrate type no longer had any effect on forest recovery between 1958 and 2010. Arable land farther from houses was reforested, while individual housing and cities sprawled mostly at the expense of the surrounding arable land. Less productive and accessible arable land was abandoned and reforested because poorly suited to the new agricultural system directed towards yield increase (large fields, motorised equipment). Traditional terraces were mostly set aside, a major trend throughout Mediterranean Europe (Sanz et al. 2013; Lasanta et al. 
2017). Meanwhile, urban sprawl replaced former arable land around urban areas (built area was multiplied by 7 between 1860 and 2010) and included the most productive soils (Fig. 4). Traditional agriculture abandonment combined with rapid urban expansion represents a major issue for arable land conservation throughout Europe, both temperate and Mediterranean (Vos and Meekes 1999; Price et al. 2015) and around the Mediterranean Basin, north and south (Marraccini et al. 2015).

From an agro-sylvo-pastoral to a simplified landscape

In 1860, the LULC spatial distribution corresponded to the agro-sylvo-pastoral system, specific of the Mediterranean area, based on the complementary use of forest, pasture and arable land (Chalvet 2006; Nogues-Bravo 2006; Puddu et al. 2012): arable land, which required frequent maintenance, was located close to built areas, while forest was confined to remote areas. Pasture was either in intermediate locations between arable land and forest, or even farther out than forest (Fig. 6). Sheep or goat herds were kept near crops to enrich the soil with their manure, and grazed on cropland during the late season. As they also needed the proximity of forests to supplement their diet, pasture was in intermediate locations. Located farther from houses were upland pastures grazed during summer, where shepherds could more easily watch over their flocks, and the topography was smoother. This may explain why pasture location was less explained by biophysical and socioeconomic drivers compared to forest and arable land.

The socioeconomic system developed in the late nineteenth century transformed the landscape through the specialisation of production systems. The nineteenth century landscape gradually turned into a dichotomy of arable land and forest during the twentieth century, as described by Barbier et al. (2010), and showed the early stages of a landscape dominated by forest, arable land and artificialized areas for the twenty first century. As slope and distance from houses were drivers of forest recovery, their effects were reinforced between 1860 and 2010, leading to a sharper spatial partitioning of forest and arable land. This spatial discontinuity has been emphasised over the last 150 years throughout the northern Mediterranean area (Taillefumier and Piegay 2003; Nogues-Bravo 2006). The traditional Mediterranean landscape has thus progressively turned into a landscape comparable to temperate lowland regions, losing its specificity due to the abandonment of traditional practices.

Our results underlined the importance of geographical context regarding the relative effects of biophysical and socioeconomic drivers. We showed that biophysical drivers explain forest recovery better than socioeconomic drivers, as in Wulf et al. (2016), but above all that socioeconomic drivers had a stronger influence on LULC spatial distribution in 1860 than subsequently. This trend might be specific to Mediterranean or mountainous landscapes, as it is in accordance with Van Doorn and Bakker (2007), while Wulf et al. (2016) and Schweizer and Matlack (2014) found that the effect of socioeconomic drivers on LULC increased with time. In our study area, the LULC distribution observed in 1860 resulted from a very long agriculture and pastoralism development in the previous centuries: during this ancient period, the importance of agriculture and pastoralism had partly overridden the biophysical constraints, and thus had weakened the statistical relationship between
Fig. 6 Spatial distribution of LULC in 1860 and 2010, adapted from Verdier (2013). This diagram includes a productivity and accessibility gradient from centre to periphery. Red: built area, yellow: arable land, light green: pasture, dark green: forest. (Color figure online)
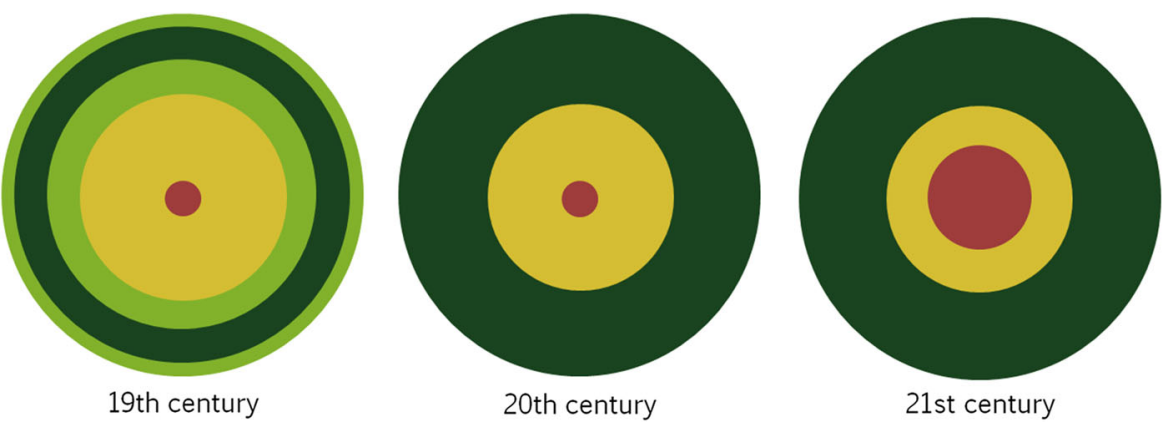
biophysical drivers and LULC. With the relaxation of agriculture and pastoralism pressure after 1860, the sites that were previously cultivated or grazed despite biophysical constraints (particularly steep slope) were preferentially set aside owing to their lower economic profitability (Taillefumier and Piegay 2003); this resulted in strengthening the statistical link between biophysical drivers and LULCs, as detected in 1958 and 2010.

Forest recovery has become independent of human decisions

As expected, proximity to pre-existing forest was a significant driver of forest recovery (Serra et al. 2008; Crk et al. 2009; Wulf et al. 2010; Puddu et al. 2012). Interestingly, we showed that the importance of this driver increased between the first and second period. From 1860 to 1958 , forest recovery was mainly shaped by biophysical and socioeconomic drivers (slope and distance from the nearest house): farmers abandoned first the least productive and least accessible land. From 1958 to 2010 however, forest recovery was much more strongly determined by proximity to tree seed sources. Our results also indicated a slight acceleration of forest recovery during the last decades. All these findings suggest that forest recovery has become an increasingly self-sustained process, implying a generalisation of land abandonment in the study area: human activities claim space closer to built areas, encroaching agricultural land, but no longer in remote areas, letting forest expand from already existing forest patches. A finer time resolution would enable us to detect whether this trend accelerated or decelerated during the last decades.

The literature records that forest recovery and deforestation are influenced by the same main drivers, such as slope, soil productivity and distance from roads (Flinn et al. 2005; Wulf et al. 2010; Mitsuda and Ito 2011), and occur close to pre-existing forest (Wulf et al. 2010; Mitsuda and Ito 2011; Schweizer and Matlack 2014). We can therefore assume that the areas reforested since 1860 may have been those that were preferentially deforested before 1860 , and that forest expansion and regression phases in previous centuries may have mainly occurred in the same areas (Paulet 1982). Thus we can expect future LULC changes to operate preferentially in these fluctuating zones.

\section{Conclusion}

Our study confirmed a major trend throughout European and particularly Mediterranean landscapes in the last 150 years: widespread forest recovery as a result of the abandonment of traditional agriculture and pastoralism, located on the most remote and unproductive land. We confirmed that the three main drivers of forest recovery were slope, distance from house and distance from pre-existing forest. We specifically showed that the main drivers of LULC were similar at the three dates, which suggests that LULC spatial distribution obeyed the same rules over a much longer time frame. We also found that extreme biophysical conditions (arable land on loose substrate and flat topography vs. forest on hard, shallow soils and steep slopes) have undergone very little change over the past 150 years. Interestingly, we showed that the part of LULC distribution explained by biophysical and socioeconomic drivers changed in time differently between temperate and Mediterranean regions, due to different long-term use of the landscape.

Acknowledgements The 1860 LULC and lithology maps were provided by the PNRL, and 1958 orthophotographs were provided by the National Institute of Geographic and Forestry Information. This work is part of a PhD Thesis supported by the Région Provence-Alpes-Côte-d'Azur and IRSTEA. The UMR 1137 Forest Ecology and Ecophysiology is supported by a Grant overseen by the French National Research Agency (ANR) as part of the "Investissements d'Avenir" Program (ANR-11LABX-0002-01, Lab of Excellence ARBRE). The authors thank $\mathrm{J}$. $\mathrm{Wu}$ and two anonymous reviewers for their constructive and helpful comments. We also thank P. K. Roche and K. Verheyen for their advice.

\section{References}

Antrop M (2005) Why landscapes of the past are important for the future. Landsc Urban Plan 70(1-2):21-34

Ballabio C, Panagos P, Monatanarella L (2016) Mapping topsoil physical properties at European scale using the LUCAS database. Geoderma 261(1):110-123

Barbier EB, Burgess JC, Grainger A (2010) The forest transition: towards a more comprehensive theoretical framework. Land Use Policy 27(2):98-107

Beale CM, Lennon JJ, Yearsley JM, Brewer MJ, Elston DA (2010) Regression analysis of spatial data. Ecol Lett 13(2):246-264

Bender O, Boehmer HJ, Jens D, Schumacher KP (2005) Analysis of land-use change in a sector of Upper Franconia (Bavaria, Germany) since 1850 using land register records. Landscape Ecol 20(2):149-163 
Bieling C, Plieninger T, Schaich H (2013) Patterns and causes of land change: empirical results and conceptual considerations derived from a case study in the Swabian Alb, Germany. Land Use Policy 35:192-203

Bivand RS (2013) Applied spatial data analysis with R. Springer, New York

Bürgi M, Hersperger AM, Schneeberger N (2004) Driving forces of landscape change-current and new directions. Landscape Ecol 19(8):857-868

Chalvet M (2006) Paysages et conflits en Provence. Rives nordméditerr 23:11-26

Cousins SAO (2001) Analysis of land-cover transitions based on 17 th and 18th century cadastral maps and aerial photographs. Landscape Ecol 16(1):41-54

Crk T, Uriarte M, Corsi F, Flynn D (2009) Forest recovery in a tropical landscape: what is the relative importance of biophysical, socioeconomic, and landscape variables? Landscape Ecol 24(5):629-642

De Keersmaeker L, Onkelinx T, De Vos B, Rogiers N, Vandekerkhove K, Thomaes A, De Schrijver A, Hermy M, Verheyen K (2015) The analysis of spatio-temporal forest changes (1775-2000) in Flanders (northern Belgium) indicates habitat-specific levels of fragmentation and area loss. Landscape Ecol 30(2):247-259

Dupouey JL, Dambrine E, Laffite JD, Moares C (2002) Irreversible impact of past land use on forest soils and biodiversity. Ecology 83(11):2978-2984

Eitzel MV, Kelly M, Dronova I, Valachovic Y, Quinn-Davidson L, Solera J, de Valpine P (2016) Challenges and opportunities in synthesizing historical geospatial data using statistical models. Ecol Inform 31:100-111

Fabre E, Vernet C (2006) Évolution de l'occupation du sol dans les Alpes-de-Haute-Provence (début du XIXe siècle - fin du XXe siècle). Méditerranée 3(4):35-42

Falcucci A, Maiorano L, Boitani L (2007) Changes in landuse/land-cover patterns in Italy and their implications for biodiversity conservation. Landscape Ecol 22(4):617-631

Flinn KM, Vellend M, Marks PL (2005) Environmental causes and consequences of forest clearance and agricultural abandonment in central New York, USA. J Biogeogr 32(3):439-452

Foley JA, DeFries R, Asner GP, Barford C, Bonan G, Carpenter SR, Chapin S, Coe MT, Daily GC, Gibbs HK, Helkowski JH, Holloway T, Howard EA, Kucharik CJ, Monfreda C, Patz JA, Prentice IC, Ramankutty N, Snyder PK (2005) Global consequences of land use. Science 309(5734):570-574

Fourchy P (1963) Les lois du 28 juillet 1860 et 8 juin 1864 sur le reboisement et le gazonnement des montagnes. Rev géogr alp 51(1):19-41

Gilbert Y (1989) Elevage, forêt et société. Analyse socio-historique. For Méditerr XI(3):203-216

Jenness J, Brost B, Beier P (2013) Land facet corridor designer: extension for ArcGIS, June 2016 edition. Jenness Enterprises. http://www.jennessent.com/arcgis/land_facets.htm

Kaim D, Kozak J, Kolecka N, Ziolkowska E, Ostafin K, Ostapowicz K, Gimmi U, Munteanu C, Radeloff VC (2016) Broad scale forest cover reconstruction from historical topographic maps. Appl Geogr 67:39-48
Kaplan JO, Krumhardt KM, Zimmermann N (2009) The prehistoric and preindustrial deforestation of Europe. Quat Sci Rev 28(27-28):3016-3034

Kaplan JO, Pfeiffer M, Kolen JCA, Davis BAS (2016) Large scale anthropogenic reduction of forest cover in last glacial maximum Europe. PLoS ONE 11(11):e0166726

Kareiva P, Watts S, McDonald R, Boucher T (2007) Domesticated nature: shaping landscapes and ecosystems for human welfare. Science 316(5833):1866-1869

Koerner W, Cinotti B, Jussy JH, Benoît M (2000) Evolution des surfaces boisées en France depuis le début du XIXe siècle: identification et localisation des boisements des territoires agricoles abandonnés. Rev For Fr LII(3):249-269

Lambin EF, Geist HJ (2006) Land-use and land-cover changelocal processes and global impacts. Springer, Berlin

Lambin EF, Meyfroidt P (2010) Land use transitions: socioecological feedback versus socio-economic change. Land Use Policy 27(2):108-118

Lambin EF, Turner BL, Geist HJ, Agbola SB, Angelsen A, Bruce JW, Coomes OT, Dirzo R, Fischer G, Folk C, George PS, Homewood K, Imbernon J, Leemans R, Li X, Moran EF, Mortimore M, Ramakrishnan PS, Richards JF, Skånes H, Steffen W, Stone GD, Svedin U, Veldkamp TA, Vogel C, Xu J (2001) The causes of land-use and landcover change: moving beyond the myths. Glob Environ Change Hum Policy Dimens 11(4):261-269

Lasanta T, Arnaez J, Pascual N, Ruiz-Flano P, Errea MP, LanaRenault N (2017) Space-time process and drivers of land abandonment in Europe. CATENA 149:810-823

Leyk S, Boesch R, Weibel R (2006) Saliency and semantic processing: extracting forest cover from historical topographic maps. Pattern Recognit 39(5):953-968

Lieskovsky J, Bezak P, Spulerova J, Lieskovsky T, Koleda P, Dobrovodska M, Bürgi M, Gimmi U (2015) The abandonment of traditional agricultural landscape in Slovakia-analysis of extent and driving forces. J Rural Stud 37:75-84

Marraccini E, Debolini M, Moulery M, Abrantes P, Bouchier A, Chéry J-P, Sanz Sanz E, Sabbatini T, Napoleone C (2015) Common features and different trajectories of land cover changes in six Western Mediterranean urban regions. Appl Geogr 62:347-356

Mather AS (1992) The forest transition. Area 24(4):367-379

Mather AS, Fairbairn J, Needle CL (1999) The course and drivers of the forest transition: the case of France. J Rural Stud 15:65-90

Mitsuda Y, Ito S (2011) A review of spatial-explicit factors determining spatial distribution of land use/land-use change. Landsc Ecol Eng 7(1):117-125

Nash MS, Chaloud DJ, Kepner WG, Sarri S (2008) Regional assessment of landscape and land use change in the Mediterranean region-Morocco case study (1981-2003). In: Liotta PH, Mouat DA, Kepner WG, Lancaster JM (eds) Environmental change and human security: recognizing and acting on hazard impacts. NATO science for peace and security series C: environmental security. Springer, Dordrecht, p 143

Nogues-Bravo D (2006) Assessing the effect of environmental and anthropogenic factors on land-cover diversity in a Mediterranean mountain environment. Area 38(4):432-444 
Odgaard MV, Bocher PK, Dalgaard T, Moeslund JE, Svenning JC (2014) Human-driven topographic effects on the distribution of forest in a flat, lowland agricultural region. J Geogr Sci 24(1):76-92

Panagos P, Van Liedekerke M, Jones A, Montanarella L (2012) European Soil Data Centre: response to European policy support and public data requirements. Land Use Policy 29(2):329-338

Paulet JP (1982) Forêts et pression démographique en Basse Provence. Méditerranée 2:31-40

Pontius RG, Shusas E, McEachern M (2004) Detecting important categorical land changes while accounting for persistence. Agric Ecosyst Environ 101(2-3):251-268

Price B, Kienast F, Seidl I, Ginzler C, Verburg PH, Bolliger J (2015) Future landscapes of Switzerland: risk areas for urbanisation and land abandonment. Appl Geogr 57:32-41

Puddu G, Falcucci A, Maiorano L (2012) Forest changes over a century in Sardinia: implications for conservation in a Mediterranean hotspot. Agrofor Syst 85(3):319-330

R Development Core Team (2016). R: a language and environment for statistical computing. R Foundation for Statistical Computing, Vienna. http://www.R-project.org/

Saas Y, Gosselin F (2014) Comparison of regression methods for spatially-autocorrelated count data on regularly-and irregularly-spaced locations. Ecography 37(5):476-489

Salvaudon A, Hamel A, Grel A, Rossi M, Vallauri D (2012) Notice de la carte des forêts anciennes du Parc Naturel Régional du Lubéron (1:40000) avec référence aux autres usages du sol. p 18

Sandel B, Svenning JC (2013) Human impacts drive a global topographic signature in tree cover. Nat Commun. https:// doi.org/10.1038/ncomms3474

Sanz ASR, Fernandez C, Mouillot F, Ferrat L, Istria D, Pasqualini V (2013) Long-term forest dynamics and land-use abandonment in the Mediterranean mountains, Corsica, France. Ecol Soc. https://doi.org/10.5751/ES-05556180238

Schweizer PE, Matlack GR (2014) Factors driving land use change and forest distribution on the coastal plain of Mississippi, USA. Landsc Urban Plan 121:55-64
Sereda S, Lukan M (2009) Assessment of changes in landuse development in the Magura and the Eastern Tatras in the years 1772-2003. Oecol Mont 18:1-13

Serra P, Pons X, Saurí D (2008) Land-cover and land-use change in a Mediterranean landscape: a spatial analysis of driving forces integrating biophysical and human factors. Appl Geogr 28(3):189-209

Taillefumier F, Piegay H (2003) Contemporary land use changes in prealpine Mediterranean mountains: a multivariate GIS-based approach applied to two municipalities in the Southern French Prealps. CATENA 51(3-4):267-296

Van Doorn AM, Bakker MM (2007) The destination of arable land in a marginal agricultural landscape in south Portugal: an exploration of land use change determinants. Landscape Ecol 22(7):1073-1087

Varese P (1990) Pré-étude en vue d'une typologie des stations forestières du Luberon. Parc Naturel Régional du Luberon, Apt, p 141

Verdier A (2013) Redécouvrir le saltus: l'exemple des pâquis lorrains. Revue de géographie historique

Vos W, Meekes H (1999) Trends in European cultural landscape development: perspectives for a sustainable future. Landsc Urban Plan 46(1-3):3-14

Vuorela N, Alho P, Kalliola R (2002) Systematic assessment of maps as source information in landscape-change research. Landsc Res 27(2):141-166

Wood SN (2006) Generalized additive models: an introduction with R. Chapman and Hall/CRC, Boca Raton

Wulf M, Jahn U, Meier K (2016) Land cover composition determinants in the Uckermark (NE Germany) over a 220-year period. Reg Environ Change 16(6):1793-1805

Wulf M, Sommer M, Schmidt R (2010) Forest cover changes in the Prignitz region (NE Germany) between 1790 and 1960 in relation to soils and other driving forces. Landscape Ecol 25(2):299-313

Zhou WQ, Huang GL, Pickett STA, Cadenasso ML (2011) 90 Years of forest cover change in an urbanizing watershed: spatial and temporal dynamics. Landscape Ecol 26(5):645-659 